\title{
Violence Against Women and Asylum Seeking: Global Problems and Local Practices Applied to Guatemalan Women Immigrating for Safety
}

\author{
Roselyn Costantino \\ Karen Smith Rotabi \\ Debra H. Rodman
}

\begin{abstract}
This paper, based on broader discussions surrounding gender violence and immigration in the U.S., provides critical information on the historical context of extreme violence against women and femicide plaguing Central American societies today. Drawing on experiences of precedent setting cases of Guatemalan women, the authors offer suggestions for culturally specific treatment of and support for women who seek asylum in the U.S. out of justified fear for their and their family members' lives should they return to their country of origin. The arguments presented are predicated on the belief that women worldwide share experiences of myriad forms of male domination and gender inequality which, however, play out differently on their bodies and lives in ways that must be accounted for in our attempt to offer them appropriate care and assist them in creating the tools they need to change their circumstances.
\end{abstract}

Key Words: Guatemala, femicide, violence against women, asylum, social work practice, immigration, battered women, PTSD, gender violence, trauma, interpersonal violence

Social workers in the United States have been committed to the welfare of immigrant populations and human rights dating back to 1889 with Jane Addams and the women of Hull House (Healy, 2008). These early service providers in the settlement house movement declared their belief in the fundamental dignity of all individuals regardless of their ethnic origins, gender, or age. They shared their commitment to provide aid so individuals could build responsible, self-sufficient lives for themselves and their families (Addams, 1961). This tradition continues today, with the focus on providing a wide array of services for families as they adjust to life in the United States. Those services, no longer carried out in settlement house communities but more broadly provided at the community level by nonprofit organizations and some government organizations, have constituted important resources for people emigrating to the United States.

Over the last decades, complex issues related broadly to globalization have placed increasing pressure on social work professionals to respond with a variety of interventions within many different human service arenas (Lyons, 2006). Notably, Latin American immigrants, who comprise the largest immigrant group to arrive in the country in contemporary history (Lopez \& Dockterman, 2011), have been the recipients of many of these services. As a result, it is imperative for social workers to learn about the sociopolitical and cultural dynamics of this diverse immigrant group.

Complicating the issues are intensifying political and social tensions in the United States over the legal status of both documented and undocumented immigrants (Gomes \&

Roselyn Costantino, Ph.D., is an Associate Professor of Spanish and Women's Studies at the Pennsylvania State University Altoona College. Karen Smith Rotabi, Ph.D., MSW, MPH, is an Assistant Professor at the Virginia Commonwealth University School of Social Work in Richmond, VA. Debra H. Rodman, Ph.D., is an Associate Professor in the

Department of Sociology and Anthropology at Randolph-Macon College in Ashland, VA. 
Ross-Sheriff, 2011). Extremely divisive in nature, these issues place even more strain on a variety of health and human service resources. Inherent problems include numerous linguistic, cultural, and legal challenges related to access to and delivery of care and, ultimately, the human rights of immigrant populations.

Numerous researchers have written about the phenomenon of violence as an immigration push factor (Morrison \& May, 1994; Zolberg, 1989). The subject, however, has not been adequately explored in the social work literature. More study is needed to include considerations of how this global problem, extending across regional, social, cultural, and economic boundaries, requires local solutions (Fischbach \& Herbert, 1997). Our goal here is to identify social work assessment and advocacy practices specifically to assist asylum-seeking clients facing deportation, particularly women whose asylum case is based on violence against women.

Because of the brief nature of this article, we focus on Guatemala as the country of origin based on our collective expertise, as we have acted as expert witnesses for survivors of violence from Central American nations, most frequently Guatemala. Guatemala is the third most-violent country in Central America (Fox, 2012) and one of the most violent in the world for women (Costantino, 2006; Sanford, 2008). Recent groundbreaking legal precedence in gender violence-based asylum cases related to this particular country are important for social workers to understand and consider when engaging with Guatemalan women and others from neighboring nations with extreme levels of violence (e.g., Júarez, Mexico; Honduras; El Salvador). Further, the authors have chosen to address Guatemalan women, who, due to Guatemala and U.S. geographic proximity and intertwined histories, constitute a large segment of the U.S. undocumented immigrant population. Their cases present a broad view of the challenges service professionals face.

With the goal of informing the practice of service professionals, the first section gives an overview of Guatemalan immigration patterns and deportation dynamics. Next is a historical overview of the origins of complex systems and attitudes underlying extreme gender violence in Guatemala, with data to support assertions and discourse about the stereotypes and common misconceptions that interfere with providing appropriate care. Then, through discussion of legal precedence and a brief profile of several cases representing significant successes and a painful loss, the article underscores critical approaches to the ethnic, cultural, linguistic, socioeconomic differences between the client and the social service provider and among the Guatemalan women clients that effectively minimize the obstacles to a successful outcome.

\section{BACKGROUND}

\section{Guatemalan Immigration Patterns, Deportation, and Gendered Dynamics}

Approximately 4 million $(3,998,200)$ Central Americans currently live in the United States (U.S. Census, 2011); more than 2 of every 5 Central American immigrants lack legal status, and 1 in 10 has some sort of temporary humanitarian protection (Terrazas, 2011). While most are seeking economic opportunities, these numbers include a small but 
significant group seeking to escape mental, physical, sexual, and economic violence. Roughly 140,000 Guatemalans arrive each year to join the more than one million who reside in the United States. Guatemalans constitute the second largest national subgroup of Central Americans in the United States, after the Salvadorans (Cohn, 2010). Of these Guatemalans, the U.S. Immigration and Naturalization Service deported 29,095 in 2010. Over the last 5 years, deportations from the United States have increased by $200 \%$ (GHRC, 2011a). The nature of these deportations results in hundreds of unattended children being left behind, unaware and unprepared for the trauma that follows (Gomes \& Ross-Sheriff, 2011). Often social workers intervene in cases of family disintegration as a result of deportation, including offering child protection and psychosocial support interventions.

Invisible in these and similar statistics are the complexity and intersectionality of the crises and the ways in which these affect women differently from men. The recognition of these differences and the intense labor of attorneys and advocates nationwide have resulted in numerous precedent-setting decisions. Perhaps the most critical has been the precedent consisting of raising women to the status of a social group, a characterization that, considering women's history in all patriarchal societies, constitutes a given to women's rights advocates. Precisely this designation created the possibility of abused women being granted eligibility for asylum, as it expands or creates nuances of legally stipulated asylum eligibility beyond persecution based on religion, political beliefs, race, and nationality. Domestic and economic violence, genital mutilation, and sex slavery are among other gender-based crimes that may be considered for eligibility under this ruling. Later we further explore the feminization of immigration in the context of Guatemala's extreme poverty and resulting social problems.

\section{Guatemala: Created and Managed through Violence}

Similar to those of most Central American countries, Guatemala's political, social, economic, and cultural histories have been shaped, at least since the 16th century, by ideologies of domination enabled through violence (Grandin, 2000, 2006, 2012). Guatemala emerged from conquest and colonization: absolute rule by elites driven by wealth and power. Roman Catholic dogma structured institutions as rigid patriarchal hierarchies. Small elites have designed economic policy to maintain control of the masses while exploiting their labor, most often with no regard for life. First Spain and then the United States used military and nonmilitary intervention that continues to prejudice statecivil society relations. The diverse local populations-Maya indigenous and ladino/mixed-consistently experience one of the largest income/wealth gaps in the world. Guatemala's 23 Maya ethnic/linguistic groups, along with poor women and children from all ethnic groups, constitute the most vulnerable and excluded citizens; Maya women, then, struggle the most. Popular images and official policies have constructed the indigenous Maya and women in general as naturally inferior members of society who, when they refuse to assimilate or follow social norms, require constant vigilance and supervision. Women, particularly Maya women, have been treated as disposable and their lives dispensable (Costantino, 2012a; Grandin, 2012), even as they 
have made and continue to make major contributions to the survival of their families and communities.

A most significant and recent event to exacerbate the misery and "violence of everyday life" (Chomsky, quoted in Grandin, 2012, p. 32) is Guatemala's 36-year Internal Conflict (1960-1996). During this war, the longest and most brutal in 20thcentury Americas (Doyle, 2012), government, military, and paramilitary forces perpetrated genocide on the Maya. With U.S. financing and training, they savagely tortured and murdered over 200,000 citizens-mostly indigenous Maya-and disappeared tens of thousands more (Doyle, 2012, p. 37). This war on civil populations created thousands of widows and orphans, and displaced over one million people (Oficina de Derechos Humanos del Arzobispado de Guatemala, 1998). As has been done for centuries, soldiers used rape as an element of war, making women's bodies the cultural symbol upon which the war played out. In the 1960s Guatemalan military members trained for, practiced, encouraged, and were forced to rape, torture, and kill with an unspeakable brutality; they often displayed publically women's mutilated bodies to create even more terror (Costantino, 2012a; Oficina de Derechos Humanos del Arzobispado de Guatemala, 1998). Very young girls to mature women were forced to serve as sex slaves. These crimes remain in almost complete impunity (Myrna Mack Foundation, 2009; Sanford, 2008). By the time of this writing, only one of the highestranking military generals responsible for the genocide has been arrested and awaits trial. Another has been recently elected president (BBC 2011; Doyle, 2012; National Security Archive, 2011; Peacock \& Beltrán, 2003). Against this enduring injustice, instead of peace and stability, the 1996 peace accords that ended the war ushered in an age marred by expanding militarization of civil society, intensifying nonmilitary violence, and a generalized sense of personal and collective insecurity as never before experienced-as it knows no ethnic, gender, socioeconomic boundaries. An explosion of ordinary crime, organized crime, drug trafficking by notorious Mexican cartels, gang warfare, and, in the service of landed elite and multinational corporations, "death squads,...now legal security companies," are ripping at the already tattered social fabric (Grandin, 2012, p 33). Guatemala is not truly "post-conflict," but rather a nation with a majority population suffering from past trauma and injustice, and extreme present insecurity and need.

\section{The War on Women: Femicide}

This insecurity is magnified by the wave of femicide plaguing Guatemala since 2001. Femicide or feminicidio - the killing of females by males because they are female, and in ways that correspond to their sexual body-has reached epidemic proportions Guatemala (Costantino, 2006; Sanford, 2008) with levels of brutality and frequency never before recorded in non-wartime. The femicide has spread to other Central American societies, such as El Salvador and Honduras (Central American Women's Network, 2010). In Guatemala and elsewhere, prosecution and conviction for gender and sexual crimes is almost nonexistent and almost absolute impunity for the perpetrator is the norm (GHRC 2009b).

Along with these more visible, "spectacular," types of violence, Guatemala's majority faces structural, systemic violence responsible for grinding poverty, high infant/maternal 
mortality, food insecurity, chronic malnutrition, and illiteracy (Lovell, 1995; MoranTaylor \& Taylor, 2010; Morrison \& May, 1994). These social problems are compounded by neoliberal economic policy and man-made environmental degradation; the last decade has witnessed persistent drought and devastating natural disasters. These stressors disproportionally affect women negatively, due to structural gender differentials in assets and earnings, all of which deepen related imbalances in access to education, health care, and physical mobility. Due to the reality that Guatemalan women are most often directly engaged in providing the basic needs of the family, the convergence of these stressors led to a "feminization" of migration patterns (Diaz \& Kuhner, 2007; Smith, 2006).

Religious factors increase the discrimination and violence women suffer as the result of unsympathetic religious leaders. Roman Catholic and evangelical Christian constitute the two major religious preferences for Guatemalan women. These churches, in tandem with nationalist discourses on family values (Chant, 2006; Costantino, 2006), insist on the woman's obligation to protect the integrity of the family unit regardless of her personal "discomforts." As a consequence of the traditional exclusion of women from economic and educational opportunities-even though her survival and that of her children are at stake-a power discrepancy remains entrenched in every aspect of her life, and by extension, her children's lives (MacCulloch, 1998). Women are shamed into staying with violent men. A woman without a male partner or husband-be she never married, separated or divorced, or widowed-is rendered dangerous in these discourses because her independence brings chaos into the order established by religious and other social institutions. Thus, women, in these terms, require male vigilance and supervision.

\section{Importance of Social Worker's Understanding of this Complicated History and Cultural Transaction in Practice}

Why is this history important to service providers to Guatemalan women seeking asylum in the United States? This knowledge provides insight into the socially formative discrimination, exclusion, abuse, and exploitation that drives women-poor indigenous Maya and ladina - to emigrate, even as persistent fear, instability, and trauma follow them here (Gomes \& Ross-Sheriff, 2011).

In addition, the profile provides a key to the savage viciousness with which men are attacking women. As part of the genocide and social reorganization, the military obliged thousands of civilian men and boys to serve in the Civil Patrol. There, they were forced to rape, murder, and mutilate members of other communities, their neighbors, and even their own family members. When the war ended, these males neither received nor had access to professional help to deal with the psychic trauma they experienced. Nor did they have job opportunities or a way to support themselves or their families. Thus, they had no chance to reintegrate into their communities, even if they survived the military's scorched-earth policy. In addition, tens of thousands of regular military, paramilitary, and death squad forces who committed the genocide, still have the guns and skills to use in their private search for a life in a decimated economy. As a consequence, the cycle of violence bears down on the women, who suffer ever more severe devaluation, discrimination, and physical violence. 
While the historical background provides perspective to the violence individual men and larger social systems perpetrate on women, it does not foreground key insights into who Guatemalan women are. Guatemaltecas, as they are referred to in Spanish, do not constitute a homogenous group, as cultural, socioeconomic, ethnic, linguistic, and religious differences are often substantial. Geography also factors into their diversity. The history of women's experiences, however, are not contained in national history, and as a result their resilience and the contributions they have made can be easily overlooked-a mistake for unaware social service providers whose concept of Guatemaltecas is based on the image of a poor and illiterate peasant with minimal ability to help herself, let alone others who depend on her. However, on the sole evidence of making the typical liferisking Mexico-U.S. border crossing in search of the security necessary to survive and provide for their children and other family members, Guatemaltecas demonstrate physical and character strength, intelligence, and resilience. They reveal their resistance to myriad forms of violence that targets and inscribes itself on their bodies and psyches.

This background information makes comprehensible indigenous Maya and other women's willingness to risk their and their family's lives to escape to the United States. Importantly, too, this brief profile suggests an additional fear they carry across two borders-Guatemala-Mexico and Mexico-United States; that is, fear of the United States itself. While relatively few U.S. citizens know about the historical and present-day effects of U.S. economic, political, and military policy in Guatemala, affected Guatemalans recognize and still experience its power; its traces are engrained in their collective memory (Grandin, 2000, 2012).

\section{HOW VIOLENCE PLAYS OUT ON GUATEMALAN WOMEN'S BODIES}

The above, necessarily brief, overview highlights the multiple sources of trauma Guatemalan immigrants carry to the United States and allows us to trace the roots of the terror ingrained in women's corporal and psychological memory. Data on the psychological effects of long-term exposure to violence, including interpersonal domestic abuse, reveal associations between that violence and mental health, observing psychological and physical consequences in the context of a woman's daily life, depression, stress-related syndromes, chemical dependency, substance use/abuse, and suicide among them (Fischbach \& Herbert, 1997).

Guatemala remains statistically one of the most dangerous places in the world to be a woman and one of the worst in the Americas to be a child (Costantino, 2006; GHRC, 2009b). Understandably, gender violence constitutes a principal reason Guatemalan immigrants seek asylum, and injury and death are only the most visible consequences (Fischbach \& Herbert, 1997, p. 1161). Guatemalan women, mostly young single mothers or heads of family, feel forced to migrate northward to feed their children and maintain their families back home (Smith, 2006). For other Guatemalan women, however, risking their life to come to the United States illegally is the last chance to save their own and often their children's lives by escaping severe physical and psychological abuse and death. Statistics confirm that their sense of terror is warranted. In 2010, police received 4,600 reports of domestic violence in that country of approximately 14 million inhabitants and the size of Tennessee. Experts believe these statistics to be low, as most 
cases go unreported for fear of retribution by a male partner, husband, other family member or other man implicated in the crime, or the police to whom it is reported (Guatemala Human Rights Commission/USA [GHRC], 2009a).

In 2010, men raped, tortured, and brutally murdered more than 800 women and girls in a surge of femicides. Since 2001, men have brutally murdered more than 5,000 Guatemalan females of all ages (3-81), social classes, and ethnicities. For the shock factor, they often leave the mutilated and dismembered bodies and body parts around town in public spaces. Of those cases of femicide, 99\% remain in impunity. (GHRC, 2011b). This gendered killing, covered regularly and explicitly by the media, reveals an institutionalized misogyny and a sense of superiority and impunity ingrained in the masculinist psyche of that nation (Costantino, 2006). Millions of women, especially those in indigenous rural and poor urban areas, live with ongoing trauma, as the escalation of violence profiled above impacts their security directly and with deadly consequences (Amnesty International, 2006; Costantino, 2006; Myrna Mack Foundation, 2009).

So unstable and insecure is life for Guatemalan women that in 2010, SecretaryGeneral of the UN Ban Ki-Moon designated Guatemala as the first UN site for its new global initiative to fight violence against women. He explained that Guatemala was selected because, although in 2008 women's organizations successfully pushed through passage of the "the femicide law," the incidence of femicide increases. This law is considered to be the first of its kind in the world, as well as the most comprehensive and progressive, as it codifies and sanctions a broad spectrum of types of violence against women. The State, however, has utterly failed to implement the new legal responses and protections made available through the law (Guatemala Human Rights Commission 2009c).

Guatemalan children, too, pay a high price for systemic and structural gender violence. UNICEF data from 2007 show Guatemala to have the highest percentage of chronically malnourished girls and boys in the Americas (over 50\%, 80\% in indigenous areas) and the fourth highest in the world (Nybo, 2009). Rates of infant mortality put Guatemala second after Bolivia (Kühlen, 2008). The UN International Labour Organization found Guatemala to have the highest rates of child labor in Central America. An estimated 1 million children work, 12,000 between the ages of 5 and 7; 56\% of them are indigenous (Avendaño, 2011).

While these statistics shed light on why women risk everything to escape to the United States, concomitantly, they disembody the injustices and crimes committed. It is precisely the body and psyche of the violated woman that concerns us, as advocates for human and women's rights. We all struggle against corruption, indifference, hypocrisy, and pure self-interest that perpetrate and perpetuate violence against women. Recently in the United States, social workers, legal advocates, women's rights defenders, and healthcare providers have had to confront these conditions of abuse as they come into contact with Guatemalan women who seek asylum in the United States. 


\section{Survivors of Violence, Asylum Seeking, and Effective Interventions}

The terrorizing lack of security in both public and private spheres for Guatemalan women, indigenous Maya, and, although not discussed in this paper, gay and lesbian citizens, render them appropriate for asylum (Central American Women's Network, 2010). Since 2009, in response to the cases of a Mexican and a Guatemalan woman, the U.S. Department of Homeland Security in a landmark decision ruled that abused women constitute a social group requiring special attention, and as such are eligible for asylum (Preston, 2009). Gender-based violence is a global issue, and advocates' arguments for asylum are predicated on the belief that women worldwide share experiences of myriad forms of male domination, gender inequities, and power imbalances. Even in developed countries or high-resource countries, researchers are identifying "deeper associations between domestic violence and a broad range of serious health and social problems" (Fischbach \& Herbert, 1997, p. 1161). Fischbach and Herbert (1997) note that in regions like Central America, with scarce material resources and greater social and political disruption, oppressive government structures, systemic non-enforcement of law, and high rates of impunity, the impact on women is magnified. According to the context in which the women exist, however, these forms play out differently on their bodies, psyches, and lives in ways that must be accounted for in our attempt to offer them appropriate care and assist them in creating the tools needed to change their circumstances.

The physical, emotional, and psychological consequences of this violence on women places increasing specialized demands on social service providers (Jones \& Horan, 1997). They must respond not only with appropriate language skills and cultural sensitivities, but also with a range of social services that, to be most effective, require additional knowledge about the client, her home country, and her particular culture (Gomes \& RossSheriff, 2011). In addition to physical medical care, clinical services with an emphasis on trauma are critically important as individuals make significant cross-cultural adjustments while reconciling past human rights violations (Burnett \& Peel, 2001). Social workers are often asked to assist with identifying low-cost legal resources and to offer expert testimony on the individual's trauma from violence, as this relates to legal grounds for asylum seeking, both previous persecution and ongoing fear of reprisal and violence.

\section{Building a Legal Case While Being Sensitive to Long-Term Treatment}

We authors have acted as expert witnesses for survivors of violence from Central American nations, most frequently Guatemala. Paramount to successfully assisting abused asylum-seeking Central American clients facing deportation, social service providers must design effective programs to make the legal case for asylum by first establishing a clear profile of the violence in context. Such strategies require exposing the structural, systemic, and culturally embedded exclusionary practices that have a material impact on the woman. The diagnosis and treatment vocabulary for women escaping gender violence in Guatemala and seeking asylum in the United States has both medical and legal consequences.

Some experts have cautioned against using the term "battered woman syndrome" and its vocabulary in preparing both a treatment plan and the legal case. They find using 
"post-traumatic stress disorder," the symptoms of which overlap with the battered woman syndrome, more efficient by avoiding the emphasis on pathology and not on a broader picture of the woman's and others' responses to the battering (Dutton, n.d.; Walker, 1991). By not recognizing women's strength and efforts, Dutton posits, the term battered woman syndrome perpetuates stereotypic images of battered women that, in the courtroom, "may inadvertently communicate to the jury or judge the misguided notion of an 'abuse excuse"" (Dutton, n.d.; Gordon \& Dutton, 1996; Walker, 1991). From a feminist perspective, classifying the trauma suffered as PTSD rather than battered woman syndrome stresses the ubiquity of this power inequality and the apparent abnormal nature of the stressors. PTSD takes the blame away from the individual woman, which is a significant goal when dealing with women from Guatemala. Similar to the stereotypes of other "third world" women, they are seen as submissive and overly religious women who accept abuse by macho men because that's just the way it is in cultures south of the Rio Grande. In other words, battering is a natural, accepted part of their culture, and they are as helpless as children (Costantino, 2012b, in press). Countering these misguided cultural visions can make the difference between life and death for the abused woman. Recognizing and aiding the woman to (re)discover her strengths and resilience are key to her taking "responsibility" and therefore credit for her recovery and adjustment.

Even the language we use to classify or describe the elements of the case affects our and others' understanding, decision-making, and social service practice. The term macho is an easy catch-all dismissive classification-it is an overused, deceptive, and even dangerous noun or adjective, as it assumes in its construction (machismo originates from Spanish) that the root of the problem lies in Hispanic/Latino/Spanish cultures. Yet, the data on domestic abuse in the United States prove otherwise: One in every four women in the United States will experience domestic violence in her lifetime, and the number of women physically assaulted by an intimate partner each year is estimated at 1.3 million (National Coalition Against Domestic Violence, 2007).

Macho creates a convenient or safe us versus them dichotomy that can interfere with the approaches to aid Guatemalan (and other Hispanic or Latina) female clients. The victimology shifts; sympathy comes to replace empathy. The strategy of helping the less fortunate (i.e., inferior, less capable) substitutes the empowerment of strong, resourceful women subjected to an individual man's or patriarchal institutional abuse. This latter abuse, when naturalized and ingrained in all social relations and institutions, renders the abused woman increasingly vulnerable as world economic crises proliferate; as militarization and intervention, in service of economic interests, intensify insecurity; and as climate change and man-made environmental devastation (open pit mining, dams, deforestation) drastically influences food production and plunge the majority of Guatemalan women into already extreme poverty and chronic food insecurity.

Caring for battered women in one's own social setting is challenging; to suddenly be confronting the layers of post-traumatic stress that Guatemalan women come with is daunting. Not only do cultural differences pose challenges on the social worker-client relationship, but language can be a significant obstacle. Many Guatemalans speak Spanish, and because approximately 50\% of Guatemalans are indigenous Maya, they speak one of 22 Mayan languages that can be so distinct as to require another native 
speaker of that language to translate from the Mayan language to Spanish and then English-as has been one author's experience. In some rural areas of Guatemala the majority of women are illiterate (MacCulloch, 1998). In addition, Maya women and poor ladina women have a deep, justifiable, suspicion of the medical establishment and intense fear of police and members of the judicial system.

In the immediate present, we need to engage in a self-reflexivity that would uncover our own preconceived notions about Guatemala, Guatemalan women, and/or abused women from any developing, "third world" country. We must continually work to create platforms for locating and then correcting the core causes of gendered violence nationally and internationally: the power inequality between women and men. Our differences may be greater than our similarities, as across cultures and geographies, identities are constructed from varying worldviews. One enduring commonality that women across the globe do share in varying degrees, however, is the inferior status allotted us by powerful social institutions - the state, religion, education, economic policy, healthcare systemsthat implicitly or explicitly condone abusive gendered behavior and resist change in the paradigm.

Knowing the facts about the context from which Guatemalan women come, then, is essential to designing approaches and practices to intervene with and help resolve conflict within a woman (inferiority complex, ingrained trauma) as well as between her and her family.

\section{CASE EXAMPLES FOR A DEEPER UNDERSTANDING INCLUDING LEGAL PRECEDENCE}

Two cases have significantly influenced the discourse surrounding and the precedence for granting asylum in the United States: Guatemalans Rody Alvarado Peña, who requested asylum and withholding of deportation in 1996, and Mindy Rodas, whose brutal murder upon her relocation to Guatemala from Mexico informs expert witnesses' supporting arguments for granting asylum in similar cases before U.S. immigration courts. Knowledgeable and culturally sensitive social service providers and client advocates are more important than ever, as the immigration debates in the United States become increasingly vitriolic and less based on constitutional and international human rights law and treaties to which the United States is signatory. The surge in violence against women and femicide related directly to economic, political, and climatic crises are affecting women disproportionately.

The case of Rody Alvarado provides an instructive example. Alvarado's legal counsel for her appeal, Karen Musalo, forced the hand of the court to recognize women as a social group, and Alvarado as a member of that social group (Elias, 2010; University of California, 2009). In this way, the outcome of Alvarado's petition for asylum goes beyond her right to remain in the country to include the expansion of this category of the eligibility for asylum under international and U.S. law. In Alvarado's case, the court established a social group "defined by immutable characteristics and fulfilled the new social visibility": abused married women in Guatemala unable to leave a relationship (U.S. Department of Homeland Security, 2004). 
For more than 10 years, Rody Alvarado's husband abused her in horrific ways. A former soldier with continued ties to the military, he repeatedly beat her unconscious, raped her, and kicked her until she hemorrhaged; he broke mirrors and windows with her head, pistol whipped her, and threatened her with a machete. Each time she attempted to get away from him, he found her and the abuse intensified. When Alvarado turned to the Guatemalan police and courts for protection, they refused to intervene in what they considered "a private matter." She attempted suicide and finally fled to the United States seeking asylum, leaving her two children with her mother in Guatemala (Elias, 2010).

Alvarado spent 14 years in an immigration status limbo in the United States. After being granted asylum the first time in 1996 by an immigration judge in San Francisco, the Immigration and Naturalization Service had the ruling overturned and asylum denied. The majority ruled that her claim did not "lie in our asylum laws as they are currently formulated" (Shelton, 1999, n. p.). This denial was then appealed and it took advocates and legal experts more than a decade to reverse it and establish new precedents in case law.

The story of Mindy Rodas is emblematic of the crisis of violence against women and impunity in Guatemala. Mindy's husband attempted to kill her by drowning, after slicing her face with a machete. This happened after he came to their home with another woman and announced he was leaving Mindy to live with this new partner. Mindy said, "Fine, I don't love you anymore," which enraged him. He attacked Mindy near a river and then left her for dead, but she survived. She received legal and economic support and medical care in Mexico to reconstruct her face. During this time after the attack, Mindy made a video in which a blue surgical mask hid her remaining facial disfiguration. She described what her husband had done to her and she encouraged abused women to come forward and reject the abuse (Rodas, 2009). Mindy still experienced post-traumatic stress, depression, homesickness, and the desire to commit suicide. Consequently, in mid-2010, she returned to Guatemala from Mexico to see her family. It should be noted that Mindy was in Mexico to seek treatment including cosmetic surgery to rebuild her face, and also as a safety precaution - as the Mexican First Lady intervened by advocating for medical care and other services for Mindy, and welcomed her to remain in Mexico. Mindy, however, felt compelled to go home, and on December 17, 2010, once back in Guatemala, she disappeared. Her body was found the next day far from her small town, tortured and strangled to death (GHRC, 2011b). Because she was found in Guatemala City and there is no national register of missing persons, another month passed before her mother learned that Mindy's unidentified body had been found the day after she went missing and then buried in a cemetery with an XX or Joan Doe designation (Portenier, 2006). Mindy joined the thousands of other women who have disappeared with Joan Doe status.

Some women, nonetheless, who attempt to escape such violence have recently won their asylum cases in the United States. Three such cases are now presented to further illuminate recent asylum rulings. 


\section{The Case of M.O. and Rosa}

The facts of Rody Alvarado and Mindy Rodas cases are known because of media attention and documentation made by human rights defenders, and in Mindy's case, by making her own testimonial video (Rodas, 2009). There are, however, many other cases which unfold in relative silence. This following case is a composite of one which a mother and daughter were recently granted asylum in the United States in the fall of 2011. It is offered as a composite to guarantee confidentiality.

M. O. left Guatemala as a 25-year old woman with her infant daughter Rosa. She crossed the border by a dangerous journey through Mexico and across the desert. M. O. chose that route as the lesser of evils - she was escaping the abuse of her husband who had repeatedly threatened to abduct her infant daughter and sell the child into human trafficking networks. Because M. O. had lived in fear of her husband for many years, after extreme physical beatings and humiliation, $\mathrm{M}$. O. had credible fears of violence and child abduction (Estrada Zapeda, 2009; Rotabi, 2012, 2009, in press).

When the authors presented expert testimony to the court, the context of violence against women formed the basis for M. O. and Rosa's case, just as Alvaro's case demonstrated. Among the facts incorporated were both the rates of femicide and the general lawlessness related to impunity. Testimony included the second author's expertise in child abuse and abduction in Guatemala, including nefarious networks of child trafficking. On examination, the most critical aspect of testimony was twofold. First, the history of abuse that M. O. experienced at the hands of her estranged husband was primary to establishing a familial context of fear nested in the larger community or societal level violence. Then secondly, the history of child abduction in the nation and an absence of law enforcement response (Estrada Zepeda, 2009; Rotabi, 2012, 2009, in press) constituted critical factors in the final determination of asylum-both mother and daughter were granted asylum.

\section{The Case of L. L.: Beyond a Narrow Definition of Violence Against Women}

Not all cases are so clear, however. Another example of women seeking asylum illustrates the complexity of gendered violence and the impunity that reigns for those who seek to harm women. More importantly, it shows that the relationship between the asylum seeker and the perpetrator is not necessarily clear in domestic situations. Social workers need to be sensitive to the fact that men in Guatemala (for example, those in and with power, such as former military and landholders) can make a claim on women who are not their domestic partners.

Recently, the third author of this article served on two cases in Boston federal court that resulted in successful asylum claims. The women's asylum claim was based on complex stories in which the abuse was not clear cut; the perpetrators were not the women's former or legal domestic partners, but had made some sort of "claim" on them. In one case, the woman had some interest in a military officer that she met through her brother. On several occasions, she had contact with the man while she was visiting her brother in the military. Although her brother warned her about the violent nature of his commanding officer, there was some flirtation until the officer attempted to sexually 
assault her. When the brother tried to intervene with the officer in his attempts to seduce the sister, the officer became violent. Afterwards, the officer was transferred to another military installation and the applicant went on to marry and have children. Over the years, however, the officer continued to pursue her and enter her life periodically. Although they were never in a domestic relationship, as far as he was concerned, she belonged to him, and consequently, the applicant and her family lived in fear.

This and other similar cases are successful because the lawyers and expert witness had a clear understanding of the larger systemic nature of impunity and gendered violence, and thus were able to argue such cases more effectively. The judge granted asylum based on his interpretation of a previous case in the matter of L. R., in which Mexican women became an eligible social group based on their on their inability to leave a domestic relationship, or they are viewed as property by virtue of their positions within a domestic relationship. Even though these two cases were not women who were in domestic relationships with their abusers, the lawyers and judges had a very nuanced understanding of gendered violence, of how women can be forced into a "relationship" without consent, and their resistance to the relationship is life threatening.

\section{SOCIAL WORK PRACTICE IMPLICATIONS: FROM GLOBAL SOCIAL PROBLEM TO LOCAL PRACTICES}

Women seeking asylum for reasons of violence, past persecution, and/or fears of future violence have multiple and diverse needs. Two areas will be considered for this brief discussion: clinical needs related to trauma and other mental health issues, and expert testimony.

It is important for social workers to understand that asylum seekers have been found to have a higher incidence of depression, anxiety, and other health conditions compared to the general population. Also, they often experience social isolation in a new country of residence (Burnett \& Peel, 2001). And while social workers may make an assessment that counseling is needed, they must recognize that women originating from traditional societies may not find such an intervention to be comfortable or appropriate, and may resist. Social workers should begin by assuming that the conceptions of counseling -in a clinical setting -is quite foreign to many women and, when possible, the women would prefer to seek help privately in the family or community group (Burnett \& Peel, 2001). Language and a client's perceptions of the power of the service providers can both pose major challenges. Relevant to these cases, one practice with a great deal of promise for helping women seeking asylum is the development of mutual aid opportunities, such as connecting with other women in a similar situation or even peer counseling. Such an intervention, based on informal social support, may be the best approximation of the care a woman would seek in her community of origin.

In order to make an assessment of appropriateness of the asylum petition, a psychological evaluation is a common practice-specifically a trauma assessment that will be used in court proceedings. This particular aspect of the investigation is critically important but often intrusive and brings up difficult memories that the survivor may prefer to forget (Burnett \& Peel, 2001). As a result, a clinical social worker engaged in 
such an assessment must understand the social dynamic and consider how to approach the survivor's history in a way to both develop a strong assessment and avoid any further trauma. Ultimately, this may be impossible, but the social worker should proceed with the greatest of caution in this clinical aspect of building a case.

A second expert witness is frequently consulted on the state of domestic violence and societal violence in the particular nation of origin. This is a particularly important aspect of developing a strong case and we authors have all participated as experts on the societal and family dynamics in Guatemala as well as other nations. It should be noted that this particular "expert witness" may be a social worker but not necessarily-experts come from a wide range of disciplines, including anthropology and women's studies. Ultimately, it is not the discipline of this individual that is central, but rather the role she or he can play in developing strong testimony on the state of violence in the country of origin and on the unique issues each case presents. This dimension of asylum-seeking strategy cannot be underestimated and it is our position that a highly articulate expert witness with years of research and practice experience in the country or region of origin can make the difference between winning and losing a legal case. Testimony carried out by such experts must be targeted and based on current data and case examples contextualized in Guatemala's history of violence against women and impunity. ${ }^{1}$ This is notable because clinical assessment for trauma and intervention by master's-level practitioners, such as licensed clinical social workers, is entirely appropriate and is likely the best strategy for ongoing practitioner care, given social work's commitment to developing support networks, using culturally appropriate interventions, and upholding deeply held values related to social justice and gendered oppression.

Ultimately, all of these aforementioned practice activities fall under both clinical and advocacy domains. Navigating such a terrain for a social worker who may come into contact with a violence survivor from Guatemala or other Central American nations requires knowledge of the problems that have been outlined in this article as well as other competencies, including language skills or access to interpretation services for Spanish and often Maya indigenous languages. Making appropriate referrals for legal assistance and offering culturally sensitive care constitute a necessary and often a daunting process for social workers.

\section{CONCLUSION}

The knowledge of the evolution of Guatemala's masculinist and racist ideologies and the practices we design to address them are intimately interrelated and essential to effectively intervening for women. While the focus here has been on Guatemalan women,

\footnotetext{
${ }^{1}$ It should be noted that most frequently this particular work is carried out by doctoral-trained witnesses ( $\mathrm{PhD}$ credential) as immigration judges prefer to hear from professionals with the highest of academic credentials in this particular aspect of case assessment. This assertion is made because master's-level practitioners who have engaged in this sort of expert testimony have experienced questioning of qualifications to make an opinion while doctoral-level witnesses are rarely challenged. This is particularly true when they have a research/publication record in the country and region under consideration.
} 
their reality is shared with women in other Central American nations with similar past and present conditions; they are also experiencing elevated rates of violence against women (Central American Women's Network, 2010). Also, women in some areas of Mexico should not be excluded, including Júarez with its notorious problems of violence against women (Fregoso \& Bejarano, 2010).

Differences in identity between groups of women and among individual women in any one country require social workers and advocates (e.g., expert witnesses and others) to create flexible frameworks from which to evaluate each woman's crisis. Without false cultural prejudice, we must empower her to self-assist, to imagine and use adequate actions. First, however, she must remove herself and/or be removed from immediate danger, and then begin the process of building a "self." This approach is time sensitive, since in the case of Central American women, the danger may follow them to the United States, where they may still lack any meaningful support system.

Advocacy is a core social work function. Advocating for changes in foreign policy or change in a sovereign nation is consistent with the National Association of Social Workers (NASW) Code of Ethics, particularly section VI that focuses on global problems and our obligations to act (NASW, 1999). We have found such action to be fundamental in forcing the U.S. legal system to confront any and all gendered and racial/ethnic biases - whether rooted in misinformation, government policy pressure, or personal prejudice - that interfere in applying asylum laws equally and without prejudice. In addition, Central American states remain "locked into the U.S. sphere of influence" (Grandin, 2012, p. 34), and this unbalanced relationship still bears heavily upon the violence women experience in their home countries, their ability to address that violence, and the treatment they receive when they arrive in the United States. The arguments presented here are predicated on the belief that women around the world share experiences of myriad forms of male domination that play out differently on their bodies and lives in ways that must be accounted for in our attempt to offer them appropriate care and assist them in creating the tools, skills, and opportunities, needed to change their circumstances.

\section{References}

Addams, J. (1961). Twenty years at Hull-House. New York, NY: Signet Classics.

Amnesty International. (2006). Guatemala: No protection, no justice: Killings of women in Guatemala. Retrieved from http://web.amnesty.org/library/index/ENGAMR340172005

Avendaño, M. (2011, September 30). Guatemala: El país donde más niños trabajan. [The country where the most children work]. Siglo 21. Retrieved from http://www.s21.com.gt/nacionales/2011/09/30/guatemala-pais-donde-mas-ninostrabajan.

BBC. (2011, November). Guatemala election views: Amnesia or a new beginning? Retrieved from http://www.bbc.co.uk/news/world-latin-america-15624222 
Burnett, A., \& Peel, M. (2001). Asylum seekers and refugees in Britain. British Medicine Journal, 322(7285), 544-547.

Central American Women's Network. (2010). Toolkit for intersection violences: Putting intersectional analysis into practice. Retrieved from http://www.cawn.org/11/index.htm

Chant, S. (2006). Female household headship, privation, and power: Challenging the "feminization of poverty" thesis. In P. Fernández-Kelly, \& J. Shefner (Eds.), Out of the Shadows. Political action and the informal economy in Latin America (pp. 125164). University Park, PA: The Pennsylvania State University.

Cohn, D. (2010). New unauthorized immigration estimates for the U.S. Washington, DC: Hispanic Center of the Pew Research Center. Retrieved from http://www.eclac.cl/mujer/proyectos/perfiles_en/

Costantino, R. (2006). Femicide, impunity, and citizenship: The old and new in the struggle for justice in Guatemala. The Journal of Mujeres Activistas en Letras y Cambio Social, 6(1), 107-121.

Costantino, R. (2012a in press). Guatemaltecas have not forgotten: From victims of sexual violence to architects of empowerment in Guatemala. In J. Roth, \& C. Rittner (Eds.), Rape: Instrument of war and genocide. In press, for May 2012 publication.

Costantino, R. (2012b in press). Enduring violence. Enduring subjectivity. Emerging trends. PsyCRITIQUES. In press, for June 2012 publication.

Diaz, G., \& Kuhner G. (2007). Women migrants in transit and detention in Mexico. MigrationInformation Source. Retrieved from http://www.migrationinformation.org/Feature/display.cfm?ID=586.

Doyle, K. (2012). Justice in Guatemala. NACLA: Report on the Americas. 45(1), 37-42.

Dutton, M. A. (n.d.). Critique of the "battered woman syndrome" model. American Academy of Experts in Traumatic Stress. http://www.aaets.org/article138.htm. Accessed 3/11/2012.

Elias, P. (2010). Federal court opens door for all Guatemalan women to claim political asylum. UN Human Right Commission Refugee Agency. Retrieved from http://www.unhcr.org/cgi-bin/texis/vtx/refdaily?pass=463ef21123\&id=4c3c03515.

Estrada Zepeda, B. E. (2009). Estudio Jurídico-social sobre trata de personas en Guatemala [Socio-judicial study on human trafficking in Guatemala]. Guatemala City, Guatemala: Fundación Red de Sobrevivientes de Violencia Domestica [Foundation Network of Domestic Violence Survivors].

Fischbach, R. L., \& Herbert, B. (1997). Domestic violence and mental health: Correlates and conundrums within and across cultures. Social Science Medicine, 45(8), 11611176.

Fox, M. (2012). Between past and present. NACLA: Report on the Americas, 45(1), 3. 
Fregoso, R. \& Bejarano, C. (Eds.). (2010). Terrorizing women: Femicide in the Americas. Durham, NC: Duke University.

Gomes, M., \& Ross-Sheriff, F. (2011). The impact of unintended consequences of the 1996 U.S. Immigration Reform Act on women. Affilia, 26(2), 117-124.

Gordon, M., \& Dutton, M. A. (1996). Validity of "battered woman syndrome" in criminal cases involving battered women. The validity and use of evidence concerning battering and its effects in criminal trials: Report responding to section 40507Violence Against Women Act U.S. (NCJRS \#160972). Washington, DC: Departments of Justice and Health and Human Services.

Grandin, G. (2000). The blood of Guatemala. Durham, NC: Duke University.

Grandin, G. (2006). Empire's workshop. Latin America. The United States, and the rise of the new imperialism. New York, NY: Henry Holt and Company.

Grandin, G. (2012). Turning the tide revisited. An interview with Noam Chomsky. NACLA: Report on the Americas, 45(1), 32-32.

Guatemala Human Rights Commission/USA. (2009a). Fact sheet: Femicide and feminicide. Retrieved from http://www.GHRCUSA.org/Publications/FemicideFactSheet2009.pdf.

Guatemala Human Rights Commission/USA. (2009b). Guatemala's endangered species: Women support I-VAWA. Retrieved from http://www.GHRCUSA.org/Publications/IVAWAGuatemalaFactSheet.pdf.

Guatemala Human Rights Commission/USA. (2009c). Guatemala's femicide law: Progress against impunity? Retrieved from http://www.GHRCUSA.org/Publications/Femicide Law ProgressAgainstImpunity.pdf

Guatemala Human Rights Commission/USA. (2011a). Fact sheet detention and deportation. Retrieved from http://www.GHRCUSA.org/Publications/factsheet_detention\&deportation

Guatemala Human Rights Commission/USA. (2011b, March). ACTUALIZACIÓN de Derechos Humanos. [ACTUALIZATION of Human Rights]. El Quetzal, 9. Retrieved from http://www.ghrc-usa.org/Publications/

Healy, L. M. (2008). Exploring the history of social work as a human rights profession. International Social Work, 51, 735-748. doi:10.1177/0020872808095247

Jones, R. F., \& Horan, D. L. (1997). The American College of Obstetricians and Gynecologists: A decade of responding to violence against women. International Journal of Gynecology \& Obstetrics 58, 43-50.

Kühlen, B. (2008). Indispensible traditional midwives in Guatemala. D+C,49(9), 323325. 
Lopez, M. H., \& Dockterman, D. (2011). U.S. Hispanic country of origin counts for nation: Top 30 metropolitan areas. Pew Hispanic Center. Retrieved from http://pewhispanic.org/reports/report.php?ReportID=142.

Lovell, G. (1995). A beauty that hurts: Life and death in Guatemala. Toronto, Canada: Between the Lines Press.

Lyons, K. (2006). Globalization and social work. International and local implications. British Journal of Social Work, 36(3), 365-380.

MacCulloch, S. (1998). Will she make it? Guatemala finds new ways to keep girls in school. Washington, DC: Inter-American Development Bank. Retrieved from http://www.iadb.org/idbamerica/archive/stories/1998/eng/e498e.htm.

Moran-Taylor, M., \& Taylor, M. (2010, Sept 10). Land and Lena: Linking transnational migration, natural resources, and the environment in Guatemala. Population and Environment, 32, 2-3. Retrieved from http://www.springerlink.com/content/1j137111516g2310/fulltext.pdf.

Morrison, A. R., \& May, R. A. (1994). Escape from terror: Violence and migration in post revolutionary Guatemala. Latin American Research Review. 29(7),111-132.

Myrna Mack Foundation. (2009). Impunity, stigma and gender: Study of criminal case files related to violent deaths in the Department of Guatemala (2005-2007). Retrieved from http://mediaresearchhub.ssrc.org/impunity-stigma-andgender/attachment.

National Association of Social Workers (NASW).(1999). Code of ethics. Revised by the 2008 NASW Delegate Assembly. Washington, DC: Author. Retrieved from http://www.socialworkers.org/pubs/Code/code.asp.

National Coalition Against Domestic Violence. (2007). Domestic violence fact sheet. Available at: http://www.ncadv.org/.

National Security Archive Guatemala Project.(2011). Guatemala project. Kate Doyle, Director. Retrieved from http://www.gwu.edu/ nsarchiv/guatemala/index.htm.

Nybo, Thomas. (2009). Fighting chronic malnutrition among impoverished Guatemalan children. Retrieved from http://www.unicef.org/infobycountry/guatemala 48087.html.

Oficina de Derechos Humanos del Arzobispado de Guatemala [Guatemala Archbishop's Office on Human Rights]. (1998). Guatemala nunca más: Informe proyecto interdiocesano de recuperación de la memoria histórica (REMHI). [Guatemala never again: Report of the inter-diocesan project on recovery of historical memory]. Retrieved from http://www.odhag.org.gt/03publicns.htm.

Peacock, S., \& Beltrán, A. (2003). Hidden powers. Illegal armed groups in post-conflict Guatemala and the forces behind them. Report. Washington, DC: Washington Office on Latin America. 
Portenier, G. (2006, May 4). Killer's paradise. British Broadcasting Corporation. Retrieved from http://news.bbc.co.uk/2/hi/programmes/this world/4965786.stm.

Preston, J. (2009, October 30). USA may be open to asylum for spouse abuse. The New York Times. Retrieved from http://www.nytimes.com/2009/10/30/us/30asylum.html.

Rodas, M. (2009, December). Mindy's nightmare. Retrieved from http://miamericas.info/2010/10/06/mindys-nightmare-video

Rotabi, K. S. (2012). El uso de la fuerza, el fraude y la coerción en algunas adopciones en Guatemala: Los casos graves de secuestros que cuestionan el principio del "interés superior del menor" [Force, fraud, and coercion in some Guatemalan adoptions: High-profile abduction cases challenge the 'best interests of the child']. Scripta Nova. Retrieved from http://www.ub.edu/geocrit/sn/sn-395/sn-395-24.htm

Rotabi, K. S. (in press). Fraud in intercountry adoption: Child sales and abduction in Vietnam, Cambodia, and Guatemala. In J. L. Gibbons \& K. S. Rotabi (Eds.), Intercountry adoption: Policies, practices, and outcomes. Surrey, England: Ashgate Press.

Rotabi, K. S. (August, 2009). Guatemala City: Hunger protests amid allegations of child kidnapping and adoption fraud. Social Work and Society News Magazine. Retrieved from http://www.socmag.net/?p=540.

Sanford, V. (2008). From genocide to feminicide: Impunity and human rights in twentyfirst century Guatemala. Journal of Human Rights, 7, 104-122. doi:10.1080/14754830802070192.

Shelton, A. (1999, November). Battered women: A new asylum case. The Progressive, 25-27.

Smith, J. (2006 April). Guatemala: Economic migrants replace political refugees. Inforpress Centroamericana. Retrieved from http://www.migrationinformation.org/Profiles/display.cfm?ID=392.

Terrazas, A. (2011, January). Central Americans in the United States. Migration information source. Retrieved from http://www.migrationinformation.org/USFocus/display.cfm?ID=821.

U.S. Census. (2011). The Hispanic population: 2010 Census briefs. Issued May 2011. Retrieved from: http://2010.census.gov/2010census/. C2010BR-04.

United States Department of Homeland Security. (2004). Position on respondent's eligibility for relief. File No: 73753 922. Washington, DC: Author.

University of California Hastings Center for Gender and Refugee Studies. (2009). Documents and information on Rody Alvarado's claim for asylum in the U.S. 19962009. Retrieved from http://cgrs.uchastings.edu/campaigns/alvarado.php\#legal.

Walker, L. E. (1991). Post-traumatic stress disorder in women: Diagnosis and treatment of battered women syndrome. Psychotherapy, 28(1), 21-29. 
Zolberg, A. R. (1989). The next waves: Migration theory for a changing world. International Migration Review, 23(3), 403-430.

\section{Author note:}

Address correspondence to: Roselyn Costantino, Ph.D., Associate Professor, Spanish and Women's Studies, The Pennsylvania State University Altoona College, 3000 Ivyside Drive, Altoona, PA 16801. Email: rxc19@psu.edu 